\title{
Identificar, acusar, expulsar: rivalidades e enfrentamentos religiosos no Brasil (1900-1960)
}

\author{
Gledson Ribeiro de Oliveira*
}

\section{Resumo}

Este artigo propõe, por meio da análise do conteúdo de jornais, revistas e processos criminais, estudar as rivalidades e os enfrentamentos religiosos entre católicos, protestantes e pentecostais no Ceará. Na primeira metade do século XX, protestantes e pentecostais concorriam com o catolicismo pelo controle do mercado de bens e serviços religiosos. O catolicismo os considerava uma infiltração estrangeira a ser banida, e os povoados, as vilas e cidades do sertão foram o principal palco das ações proibitivas diretas e indiretas que objetivavam identificar, censurar e punir as condutas desviantes. Já os pentecostais foram desclassificados como religião cristã tanto pelos católicos quanto pelos protestantes por praticarem o que chamavam de baixo espiritismo.

Palavras-chave: Católicos versus Evangélicos; Censura Religiosa; Ações Proibitivas; Violência.

\section{Identify, accuse, expel: rivalries and religious clashes in Brazil (1900-1960)}

\section{Abstract}

This article proposes, through the analysis of the content of newspapers, magazines and criminal processes, to study the religious rivalries and clashes between Catholics, Protestants and Pentecostals in Ceará. In the first half of the twentieth century, Protestants and Pentecostals competed with Catholicism for control of the market for religious goods and services. Catholicism regarded them as a foreign infiltration to be banished, and the villages, towns and cities of the hinterland were the main stage of direct and indirect prohibitive actions aimed at identifying, censoring and punishing deviant conduct. Pentecostals were, however, disqualified as a Christian religion by both Catholics and Protestants for practicing what they called low spiritism.

Keywords: Catholics versus Protestantism; Religious Censorship; Prohibitive Actions; Violence.

* Professor da Universidade da Integração Internacional da Lusofonia Afro-Brasileira (UNILAB); Licenciado em História (Universidade Estadual do Ceará), doutor em Sociologia (Universidade Federal do Ceará). Email: gledsonribeirodeoliveira@gmail.com 


\section{Identificar, acusar y expulsar: rivalidades y enfrentamientos religiosos en Brasil (1900-1960)}

\section{Resumen}

Este artículo propone, a través del análisis del contenido de periódicos, revistas y procesos criminales, estudiar las rivalidades religiosas y los enfrentamientos entre católicos, protestantes y pentecostales en Ceará. En la primera mitad del siglo veinte, los protestantes y los pentecostales compitieron con el catolicismo por el control del mercado de bienes y servicios religiosos. El catolicismo los consideraba como una infiltración extranjera para ser desterrados, y las aldeas, pueblos y ciudades del interior eran el escenario principal de las acciones prohibitivas directas e indirectas destinadas a identificar, censurar y castigar las conductas desviadas. Sin embargo, los pentecostales fueron descalificados como religión cristiana tanto por los católicos como por los protestantes por practicar lo que llamaron bajo espiritismo.

Palabras Clave: Católicos versus Evangélicos; Censura Religiosa; Acciones Prohibitivas; Violencia.

\section{Introdução}

A primeira metade do século XX é um tempo profícuo para análise e compreensão das rivalidades e enfrentamentos face a face ${ }^{1}$ entre católicos, protestantes e pentecostais ${ }^{2}$. Nele, o catolicismo formalizou seu projeto teológico-político de 'restauração' e as igrejas protestantes e pentecostais, minimamente organizadas e com fomento estrangeiro, arrebanhavam mais prosélitos e se capilarizavam por todo o território nacional. Desde a Pastoral Coletiva de 1915 e a Carta Pastoral de Dom Sebastião Leme (1916), o clero incitava o combate ao que chamava de 'infiltração protestante’3. O laicato de

1 Conforme Max Weber (2009, p.23), luta pacífica é concorrência, rivalidade. A luta ou concorrência típica difere-se da luta violenta por sua peculiar normalidade social, em que se busca impor ao Outro sua própria vontade e pelo desejo de dispor "sobre oportunidades desejadas também por outras pessoas". Em algumas situações, as rivalidades entre protestantes e católicos evoluíram para enfrentamentos face a face por meio do que chamaremos de ações proibitivas diretas.

2 Será utilizada o termo protestantes para as igrejas de origem missionária estadunidense, isto é, a igreja batista e presbiteriana, e pentecostais para as igrejas Assembleia de Deus e Evangelho Quadrangular. Na tipologia de Paul Freston (1993), elas são, respectivamente, igrejas da primeira e segunda onda pentecostal. Na tipologia de Ricardo Mariano (1999), pertencem, respectivamente, ao pentecostalismo clássico e ao deuteropentecostalismo. A Igreja Universal do Reino de Deus pertence à terceira onda pentecostal ou ao neopentecostalismo.

3 Para o clero, o número de agências e de igrejas estrangeiras reforçava a impressão de que estava em curso uma invasão protestante. O padre Agnelo Rossi (1938) publicou n'O Diretório Protestante no Brasil o primeiro balanço histórico e estatístico sobre a presença protestante e pentecostal no país e denunciou a afinidade eletiva entre as missões protestantes e as empresas estadunidenses. 
classe média da Ação Católica, mobilizado pelo clero e animado pela teologia da neocristandade, buscou reconquistar o poder pastoral da Igreja sobre a sociedade, ocupando e exercendo influência na esfera pública. Entrementes, protestantes e pentecostais criam estarem em uma cruzada salvacionista no continente latino-americano e pelejavam para terem supridas suas demandas por reconhecimento cultural e religioso em uma sociedade que consideravam idólatra e cujo Estado, amancebado com o clero, era laico apenas no papel.

Em um território hegemonicamente católico, o proselitismo era um investimento arriscado, e não raras vezes as polêmicas entre padres e pastores em jornais e livros descambavam para as ações diretas contra protestantes e pentecostais. Definiremos como ações proibitivas diretas e de censura ações indiretas - o conjunto de atividades que tinham por objetivo identificar, acusar e conter o proselitismo e a cooperação com evangélicos, bem como constranger, perseguir e expulsar convertidos da comunidade. Cabia aos bispos e padres orquestrar as ações valendo-se da sua posição privilegiada junto ao povo e dos instrumentos próprios da Igreja para garantir reverência e observância às recomendações clericais e às normas previstas no Direito Canônico. Ao mesmo tempo em que denunciava e estimulava no púlpito e pelos jornais o combate à invasão de igrejas e "seitas estrangeiras", o clero vigiava diocesanos e censurava os comportamentos desviantes, quando não instigava a realização de marchas em desagravo e a mobilização de multidões religiosas pelo Ceará e alhures. Em suma, as ações proibitivas e de censura visavam impedir a cooperação e que o infidelizado "leve sua vida como bem entenda", na boa expressão de Paul Ricouer (2000, p. 20).

As rivalidades entre a religião oficial e as religiões outsiders tinham por fundamento último a luta pela produção de sentido e pelo controle sobre a distribuição dos bens e serviços religiosos. Trabalhadores incansáveis das representações e ideologias religiosas, pastores, bispos e padres concorriam no mercado pelo "poder de fazer ver e crer" (BOURDIEU, 2007, p. 444), isto é, pelo poder de definir quem está autorizado a interpretar a 'verdade bíblica', de como a religiosidade cristã deve ser vivenciada (ALVES, 1982), e de quem está autorizado a mobilizar a memória religiosa que liga a comunidade moral à linhagem de crença cristã (HERVIEU-LEGER, 2005).

É recorrente, na historiografia e na sociologia de fundo confessional, definir as ações diretas e de censura como atos de perseguição e intolerância religiosa (Cf. TARSIER, 1936; RIBEIRO, 1991; FERREIRA, 1992). Há alguma razão para isso. Pode-se argumentar que uma boa parte das evidências 
é de jornais e livros protestantes. Isso, contudo, não anula algumas outras escritas pelo próprio clero e publicadas em seus veículos. Além disso, é imperioso trazer a lume, também, as evidências produzidas pelas próprias igrejas protestantes, em particular a igreja presbiteriana e batista, acerca dos seus rivais católicos e pentecostais. O caráter abertamente militante dos jornais diocesanos, presbiterianos e batistas os torna um celeiro de representações que documentam com exatidão o que católicos e evangélicos pensavam uns dos outros. Tratando-se de uma investigação cujo objeto é pretérito, o método foi a análise de conteúdo dos artigos da imprensa religiosa, de transcrições em livro ${ }^{4}$ e de um processo judicial. Destarte, interessa aqui contribuir com mais um fragmento local, no contexto da região Nordeste ${ }^{5}$, para os estudos sobre as rivalidades e os enfrentamentos religiosos no Brasil.

\section{Identificar, acusar, expulsar}

Em O bode expiatório (2004), René Girard explicou que o mimetismo coletivo é um mecanismo de grupo que indica, por meio de um signo gesto, texto, ícone, símbolo - um comportamento a ser seguido. Analisando a negação de Pedro no evangelho de Marcos, comentou que, quando uma das servas do palácio de Pilatos o denunciou como seguidor do Cristo, ela esperava que os demais a imitassem em seu gesto, o que aconteceu apenas na segunda tentativa quando a assistência proferiu: "de fato és um deles; pois és galileu”. Para Girard, a serva aciona a máquina mimética que desencadeia a perseguição coletiva. Estereotipadas, as perseguições coletivas possuem um padrão situacional e de comportamento identificável: a existência de uma crise que afeta a comunidade, uma acusação de crime, a marca vitimária que carrega o acusado - doença, deformações, pertencimento étnico e religioso...

\footnotetext{
4 O livro do memorialista Paulo Viana, A sagrada Peleja (2001), é uma importante coletânea de artigos escritos pelo pastor presbiteriano Natanael Cortez. Contudo, não há o título dos artigos e o nome do jornal em que foram publicados. $\mathrm{O}$ organizador também não diferenciou o dia de redação do texto da data de sua publicação.

5 No período em questão, os estados do Nordeste eram os menos evangélicos do Brasil. O item 'protestantes' apareceu pela primeira vez no Censo Demográfico de 1890 , contabilizando 143.743 fiéis em todo o país. No Ceará, registraram-se nesse Censo os 526 adeptos ao protestantismo, ultrapassando a segunda maior religião, a positivista. Em 1940, os evangélicos somavam 6.794 adeptos (0.32\%), no Censo de 1970 passaram a 69.083 (1.58\%), e alcançaram, em 1991, 252.133 filiados (3.96\%). Em 2010, eram 1.236.435 pessoas, representando $14,5 \%$ da população. No Censo Demográfico de 2010, a região Nordeste permaneceu a menos evangélica, com $16,39 \%$.
} 
-, e a sentença que restabelece o equilíbrio social através do fenômeno do bode expiatório ou a vítima sacrificial ${ }^{6}$. Seja pela execução da lei ordinária seja pela justiça popular, somente a prisão, o linchamento ou a expulsão da comunidade restaura a ordem social abalada.

A mecânica das ações proibitivas diretas é similar a das perseguições estereotipadas. Pensando com Girard, as ações proibitivas também são desencadeadas em um momento de crise. Que crise é essa? Não se trata de uma má colheita ou peste, mas de uma mudança na rotina religiosa da comunidade, tal como a presença de um missionário ou colportor. No sertão místico, o católico vivenciava a sua crença como os seus bisavôs. Continuava realizando procissões, novenas, reisados, rezava o terço, alimentava a economia do toma-lá-dá-cá com os santos, adorava um Cristo sofredor com sua teologia da paixão e até podia se tornar profeta ou transformar hóstia em sangue. Nessa cena religiosa bucólica, uma pregação ou distribuição de bíblias e folhetos seria, por si, uma transgressão dos costumes que exacerbam os sentimentos de pertença religiosa e desencadeiam a tríade proibitiva: identificar, acusar e expulsar. $\mathrm{Na}$ comunidade há sempre um membro que identifica a pessoa com a marca vitimária, isto é, um comportamento desviante. Os padres estão no topo da atividade panóptica e são os primeiros a desencadear as ações proibitivas. No artigo "Uma viagem de colportagem", publicado pelo Norte Evangélico" de 22 de agosto de 1917, narra-se o trabalho de dois colportores presbiterianos, Valentim Alves e Antão Pessoa, pelo sertão nordestino. Segundo o relato deles, ao chegarem à cidade do Crato "foram vaiados pelo povo", prevenidos que estavam pelos padres. Distribuindo poucas bíblias, seguiram para Juazeiro e hospedaram-se na casa de um turco de nome Armando Dalate, "segunda pessoa do padre Cícero, o general-em-chefe das tropas do sultão de Juazeiro”. Os colportores continuaram a narrativa relatando:

Em juazeiro não se dá um passo sem conhecimento do sultão tonsurado, pelo que os colportores foram obrigados a comparecer à sua presença antes que pudessem fazer qualquer trabalho. Foram levados pelo turco que, depois de romper por entre uma multidão de mais de duzentas pessoas, que se apinhavam a porta do padre, à porfia de audiência, os introduziu à presença

\footnotetext{
6 Não é possível aqui deixar de mencionar o anaforismo entre a alcunha 'bode', visto no tópico anterior, e o bode expiatório da teoria mimética girardiana. Entre os dois, guarda-se apenas a semelhança morfológica.

Órgão de imprensa das igrejas presbiterianas pertencentes ao Presbitério do Norte do Brasil.
} 
do santo sultão. Este, depois de interrogados viajantes e saber quem eram e qual a missão, abriu a imunda boca e fez um discurso composto das mais vis falsidades e nojentas calúnias contra os reformadores, as sociedades bíblicas e a religião evangélica, em linguagem tão insultuosa que tocava o auge do atrevimento, tudo isso em tom autoritativo a não permitir articular uma só palavra em defesa findou proibindo terminantemente que se vendesse ou se espalhasse um só exemplar dos evangelhos e ameaçando com penas rigorosíssimas a quem pusesse mão num dos livros. (...) Perguntado pelos colportores se considerava falsos os livros, padre Cícero respondeu negativamente, mas insistiu que de modo algum deviam ser lidos, porque resultariam da leitura e heresia, a perversão da crença católica e a condenação eterna. Assim foram despedidos os colportores, que só muito as escondidas puderam fazer presente de dois ou três exemplares. Era que o povo, extremamente fanatizado, não ousava tocar idéias com os colportores e, ao avistarem-nos, benziam-se com receio do demônio e da excomunhão do santo padrinho padre Cícero (Sic) $)^{8}$.

A longa citação é necessária menos pelo tom ressentido que por seu conteúdo esclarecedor. Antecipando-se à empresa evangélica, Padre Cícero mandou chamar os dois à sua presença. Depois de atravessarem uma multidão de duzentas pessoas que jazia à sua porta, o coronel de batina impõe silêncio enquanto discorre sobre os erros do protestantismo. A marca vitimária é óbvia: eram emissários de uma religião apóstata e distribuíam bíblias na versão Almeida9. Após o "interrogatório", Padre Cícero sustenta a acusação: estavam em Juazeiro do Norte para espalhar livros heréticos que pervertem a fé do povo. Sentença: a expulsão da cidade. De saída, os dois colportores ainda desafiaram a ordem do padre e distribuíram algumas Escrituras.

Nem todo o clero possuía a autoridade carismática de um Padre Cícero, o que exigia alguma criatividade para desencadear as proibições. Provocações públicas podiam ser usadas para induzir a comportamentos tipificados como crime e levar pastores e convertidos à prisão ou mesmo à expulsão da comunidade. Em 11 de novembro de 1924, na cidade do Cedro, o aguerrido Padre José Correia Lima acionou o artigo 185 do Código Penal de 1890, Capítulo III, sobre Crimes contra o livre exercício dos cultos, que prescrevia a

\footnotetext{
8 Nas citações de documentos e transcrições, transcrevemos o texto tal como encontrado.

9 A Bíblia traduzida por João Ferreira de Almeida a partir de manuscritos gregos e hebraicos foi finalizada apenas em 1748 por missionários na Índia. Difere da Vulgata Latina, de 1778, do padre Antônio Pereira de Figueiredo, conhecida como Versão de Figueiredo por não ter sete livros: Tobias, Judith, Sabedoria, Eclesiástico, Baruch, e Machabeus 1 e 2.
} 
prisão a quem ultrajasse a prática e os objetos de culto religioso, desacatasse ou profanasse seus símbolos publicamente ${ }^{10}$. Na lógica do padre Lima, um desacato à sua autoridade de sacerdote seria suficiente para dar voz de prisão a quem quer que fosse. Esmolando pelas ruas em prol de São João, padroeiro da cidade, aproximou-se um "crente" de nome Batista Albuquerque e pediulhe "uma esmola para S. João"; Batista disse-lhe: "Eu não dou Sr. Vigário, desculpe, eu não dou esmola para a igreja". A conversa prosseguiu. "Por que não dá? / Eu não dou, porque sou protestante. / Não dá porque é besta. / Besta é quem dá, Sr. Vigário. / Cabra atrevido! Esteja preso!”. Encaminhado para a delegacia por um soldado, Batista Albuquerque foi solto por autoridade superior quando soube do motivo da prisão. Dias depois, o padre foi mais invasivo quando tomou a bíblia de um tal José Sobreiro e a rasgou em público (VIANA, 2001, p. 246). Acusar de desrespeito e acionar a polícia foi uma estratégia de contenção bem difundida. O órgão da diocese de Sobral, Correio da Semana, noticiou que, na cidade de Ipú, dois presbiterianos que pregavam durante o passeio das "famílias de elite" foram levados à delegacia acusados de chamar de "canalha a sociedade do Ipú" e o catolicismo de religião de "exploradores e fanatizadores"11. Em Sobral o Correio também registrou que, após "os crentes" exibirem um filme, de conteúdo ignorado, iniciaram a pregação que teve que ser suspensa pelos soldados em nome da "tranqüilidade pública", pois os moradores queixavam-se de que eles insultavam a Igreja Católica e o bispo Tupinambá da Frota ${ }^{12}$.

É problemático dimensionar o papel dos agentes públicos nestas situações limites: se em benefício de pastores, como no caso do Cedro em 1924, ou contra, como no caso de Ipú e Sobral. As autoridades policiais oscilaram entre permitir o livro curso e, às vezes, encabeçar as ações proibitivas, e cumprir os artigos da constituição que regiam sobre a liberdade de culto. Nas evidências analisadas, pelo menos em duas ocasiões, a polícia garantiu o que o pastor presbiteriano Natanael Cortez chamou de "certos direitos que nos confere a nossa Constituição de 24 de fevereiro [1891]" (VIANA, 2001, p. 95): a primeira, quando da ameaça de apedrejamento durante um culto em Quixadá; a segunda, quando, novamente, o padre Lima lutou contra a construção de um "templo

10 "Art. 185. Ultrajar qualquer confissão religiosa vilipendiando acto ou objecto de seu culto, desacatando ou profanando os seus symbolos publicamente: Pena - de prisão cellular por um a seis mezes." Código Penal de 1890.

11 Insolências dos protestantes no interior. Correio da Semana. 28 maio 1932. p. 04.

12 Igreja Presbiteriana de Fortaleza. Norte Evangélico. fev. 1957. p. 08. 
protestante" em um terreno dedicado ao santo São João. Não obstante, a interpretação do clero sobre a liberdade religiosa era de outro tipo. Consideravase que a Constituição não dava direito aos evangélicos de dizer ofensas à religião do povo brasileiro. Em artigo do Correio da Semana do dia 31 de março de 1932, registrou-se: "O poder constituído, seguro de suas atribuições, não reconhece faculdade de se promoverem comícios atentatórios às convicções espirituais do povo". O redator queixou-se ainda de que a polícia estava a ser usada para intimidar o povo católico, "para obrigar os filhos da Egreja a abraçarem espontaneamente a sua doutrina". Pode-se concluir que, em meio aos conflitos, o papel das autoridades variou segundo a correlação de forças entre poder público e Igreja local. Onde o alinhamento entre religião e Estado foi rigoroso, como em Juazeiro e Sobral, havia pouco espaço para o domínio da lei ou o emprego da noção de estado de direito, isto é, do uso da norma jurídica em favor dos pastores, impondo limites às ações proibitivas, como foi o caso de Quixadá. Entre a norma jurídica que regia a liberdade religiosa e a sua execução, havia uma distância de interpretações e condutas sobre as quais os pastores tinham apenas a expectativa de ser ao seu favor. No artigo em que narram o encontro com o Padre Cícero, os colportores registraram, ainda, que, em São José dos Pinhais, na Paraíba, foi o delegado que os proibiu de vender e distribuir livros. Ao invocarem seus direitos constitucionais, ele respondeu "que não conhecia outra constituição além de sua vontade", ordenando que se retirassem imediatamente, sob a ameaça de prisão.

\section{As multidões religiosas}

As multidões religiosas têm por objetivo festejar a unidade de fé e sacralizar o espaço público da cidade por meio da marcha, procissão, romaria ou missa/culto ao ar livre. Eventualmente, contudo, elas irrompem nas ruas para intimidar e, em casos extremos, expulsar outsiders da comunidade ${ }^{13}$.

13 A teoria contemporânea das multidões deslocou a análise das formas de controle, patologização das ações coletivas e da adesão por 'contágio' para o mapeamento dos padrões comportamentais e dos processos de adesão e de submissão do indivíduo ao grupo. Na multidão o indivíduo não perde de todo a sua singularidade, os papéis sociais não são rígidos, as normas de convivência emergem de acordo com as interações, e os participantes compartilham os mesmos laços de pertença e de crença, identificando-se com a prática de seus membros mais atuantes. Para um comentário sobre as teorias contemporânea das multidões, ver Boudon (1995). No campo da história social, ver o estudo de Marc Bloch sobre as multidões de enfermos e os reis taumaturgos na Inglaterra e França; as multidões da Reforma Protestante, analisada por Natalie Davis; e os saques aos bens papais na Roma do século XVI, de Carlo Ginsburg. 
Em 1932, na cidade de Sobral, o Correio da Semana noticiou que, enquanto quatro praças davam apoio a um pastor, que "insultava cruelmente a Egreja Catolica”, perto do Theatro São João, Dom Tupinambá da Frota convocou o povo a desfilar pelas ruas da cidade e concentrar-se em frente ao Palácio do Bispo contra a pregação. Anos depois, em dezembro de 1940, a tensão chegara ao ponto de a autoridade policial solicitar que deslocassem de Fortaleza "um caminhão com soldados para levarem preso para alli o Sr. Bispo de Sobral!", uma rara tomada de posição de uma autoridade policial contra um membro destacado da Igreja.

É característica da multidão a figura do líder. O líder pode conduzi-la ou se destacar ao longo da ação. Em um ou outro caso, a sua função é dar objetivo ao coletivo para que não se disperse. Mas quem lidera a multidão pode não ser a mesma pessoa que a articulou. O bispo Dom Tupinambá, por exemplo, incentivou a passeata em Sobral, mas deixou a seus comandados a condução da ação direta. Situação diferente ao que aconteceu em Cedro, em julho de 1925, na qual o padre Lima assumiu os dois papéis. Natanael Cortez solicitou proteção ao delegado para realizar um culto e, a certa altura da pregação, um confrade apareceu querendo falar-lhe. Ao longe vinham em direção da casa centenas de pessoas, "e nada do delegado". O confrade "tomou à frente e a muito pedido conseguiu acalmar o povo e o padre Lima que estava em fúria terrível...". Mais tardar da noite, o padre preparou uma passeata, fazendo o discurso "de que se devia repelir o protestantismo, ainda que se derramasse sangue até o meio da perna...". Dias depois, o presbiteriano Teixeira Gueiros despachou um telegrama dizendo que, apesar de o delegado estar presente, as manifestações hostis continuavam. "Há pouco multidão chefiada pelo padre Lima percorreu ruas dando morra protestantes vivas padre que fez discurso concitando destruição aos evangélicos" (VIANA, 2001, p. 259).

Em outro caso, acontecido em Barbalha, região do Cariri, lavrouse um sumário de culpa, com data de 1940, em que figura como réu um funcionário municipal de iniciais A. S. B, acusado de invadir um culto protestante e de destruir duas Bíblias. O palco onde se desenrola a ação é a residência de um barbeiro de nome Luiz Gonzaga de Sousa, onde, a convite, o pastor da Igreja Batista de Juazeiro, Marceonilio Francisco, e o missionário estadunidense, Guy MacLain, realizavam um culto. Em comparação a outras evidências, a vantagem do sumário é que nele há diferentes versões sobre um mesmo acontecimento. Na versão do queixoso pastor Marceonilio, o 
culto fora "assistido da rua por uma grande multidão, a princípio calma, mas que veio a se transformar hostil e ameaçadora com a chegada mais tarde do Padre José Correia Lima, acompanhado por numerosas pessoas". Depois de rasgar as Bíblias, voltou para a casa e tentou agredir os crentes “aos quais ameaçou esbofetear”. Só após o delegado especial dispersar a multidão, encerrou-se o culto. Ainda em seu depoimento, o pastor afirmara que o padre estava entre a multidão de quatrocentas pessoas que "não só cantava hinos da religião católica como procurava ofender a sua pessoa e dos outros adeptos com assobios, gritos e uma pedra...”. Uma das testemunhas arroladas confirmou que o culto em que participavam três mulheres e dois homens, além de familiares do barbeiro, havia sido interrompido por "A.B.S, bastante embriagado, e começou chamar os protestantes de bode e de cachorros dizendo que hoje que eles apanham é na cara". Entrementes, o padre procurou retirar as pessoas quando o acusado supostamente teria levado as Bíblias, depois as rasgando. Após encerrar o culto, o pastor Marceonilio disse que seguiu com Guy MacLain para o carro, que logo foi cercado. Ao tomar o automóvel, "recebeu um soco de uma das pessoas que rodiavam o veiculo". Chamado para depor, o delegado falou que a família do barbeiro era a única convertida na cidade, uma "redusida menoria de adeptos da religião protestante de menor de um por cento da população desta cidade". Em seu depoimento, o padre Lima disse que foi avisado de que muitas pessoas seguiam para o local onde se "reuniam uns protestantes". Quando chegou, encontrou a multidão "resando, cantando e vivando Cristo Rei, Nosso Senhor Jesus Cristo, Maria Santíssima Santo Antonio Padroeiro da Freguesia e São Vicente de Paula". E, para evitar "desrespeito à ordem pública", subiu em uma cadeira e pediu que a multidão o seguisse para a Igreja. Já A.S.B. relatou, em sua defesa, que, apesar de estar alcoolizado, não rasgou as bíblias e sim um homem de iniciais J. S., a quem as entregou. Depôs ainda que se juntou à multidão quando o padre Lima chegou acompanhado de "numerosa multidão" em direção a uma casa em que estavam reunidos os "crentes".

Não é possível precisar se houve a condenação do réu, pois a pasta dos autos fora desmembrada. Mas a conclusão do inquérito tipificou o seu comportamento como de flagrante delito contra "os direitos constitucional de liberdade de culto, por meio de uma manifestação hostil adredemente preparada". O advogado de defesa tentou diluir a culpa que pesava sobre ele ao argumentar que o ocorrido havia sido um "crime de multidão". Todavia, na multidão sem rosto, o dele não se deixou esquecer. $\mathrm{O}$ anonimato não foi 
possível. O padre Lima figurou como apaziguador, recaindo toda a culpa do delito sobre o réu. Neste caso em Barbalha, a mimese foi um importante elemento indutor do comportamento da multidão. Mesmo que não esteja evidente quem a preparou e comandou, o comportamento do líder foi seguido por centenas de moradores e, durante a ação, os participantes assumiram o protagonismo. Como multidão religiosa, todos ali possuíam uma mesma economia moral, qual seja, a convicção de estarem a defender sua crença, sentimento que lhes deram força e legitimidade no curso da ação. A ação coletiva só findou com o encerramento do culto, a destruição de bíblias e a expulsão dos missionários. Só a tríade proibitiva dissipou a energia da multidão persecutória.

\section{Censura, boatos e histórias fantásticas}

Nas ações proibitivas indiretas, o Correio da Semana, fundado pela Diocese de Sobral em 1918, e O Nordeste, órgão a serviço da Arquidiocese de Fortaleza que passou a circular em 1922, além de darem notícia sobre a vida clerical, os estudos doutrinários e os acontecimentos da catolicidade internacional, foram usados como um instrumento de censura pública e de difusão de boatos acerca de pastores e pessoas que cooperavam com o trabalho protestante. No tocante ao que chamavam de cooperação com a empresa protestante, no ano de 1932, em Sobral, o Correio da Semana censurou o diretor da via férrea por permitir o livre curso da propaganda protestante nos vagões de trem da Rede de Viação Cearense. Intitulado os "Protestantes amparados", o diretor da rede foi indiretamente advertido nestes termos: "Os trens andam tão atrazados e o comercio tão prejudicado com a deficiência sempre crescente do material rodante! Já terá havido uma recomendação ao Snr. Ministro da Viação neste sentido?...". Outro caso foi a Portaria intitulada "Aviso 331", do bispo Antônio Lustosa, comunicando às famílias cearenses que cooperar direta ou indiretamente com o protestantismo era uma falta grave passível de excomunhão. Publicada n'O Nordeste de 21 de janeiro de 1950 , ela falava da abertura de um "Colégio oficialmente protestante" - o Colégio Batista - e da proibição a todo católico de trabalhar e matricular seus filhos ou dependentes. Definia-o como um "colégio herético", contrário à instrução educacional e um "doloroso" golpe ao povo cearense que colocava em perigo o "patrimônio precioso da fé católica". Ao final da Portaria, alertava-se que os sacerdotes deviam exortar os pais, tutores, patrões e professores sobre as "penas" que a Igreja lhes reservava caso infringissem as 
resoluções do Primeiro Concílio Brasileiro de 1939 e do Código do Direito Canônico, que, em voga desde 1917, rezava, no artigo 1.374, a interdição de matrícula em colégios mistos e acatólicos. Os pais desobedientes estavam passíveis de desligamento da Igreja e os professores incorriam no "pecado de cooperação". O espaço escolar era um importante lugar de produção e reprodução do modo de vida católico. Fazia-se necessário desautorizar a autoridade pedagógica concedida aos colégios protestantes pelo Estado e recomendar aos fiéis a matrícula em instituições que só ensinassem o catecismo católico ${ }^{14}$.

Outro mecanismo de censura, a divulgação de boatos e de histórias fantásticas pelos jornais, contribuiu para consolidar as representações que formavam a verve popular sobre o protestantismo. A eficácia dos boatos e histórias aumentava conforme as vezes em que esses circulavam e eram reproduzidos. O primeiro número d'O Nordeste, de julho de 1922, estampou a epígrafe “Os protestantes proscrevem o nome de Jesus Cristo!!!”. O artigo registrava que, na fronteira missionária indiana, os pastores suprimiram o nome "Jesus Cristo" dos livros de orações e hinos usados nas escolas de missões para não ofender a crença hindu e maometana. Outra acusação bastante comum foi espalhada pelo Correio do Ceará em março de 1932, de que os batistas tinham "ódio" à Virgem Maria, praticavam o "rebatismo" e que não criam no Cristo. Além de boatos, alguns relatos e notícias associavam pastores, missionário e convertidos a situações extraordinariamente malignas. Ora, o imaginário popular admitia a crença em seres fantásticos como o Chupa-cabras, a Mula-sem-cabeça ou o Caipora, o que tornava razoável a crença em histórias de que uma pessoa pudesse ter marcas corporais demoníacas. Conforme Todorov (2012), o coração das histórias fantásticas

14 Um caso que não envolveu diretamente o clero mas que teve ampla repercussão n'O Nordeste foi o debate sobre as origens da capital cearense. Pesquisadores do Instituto Histórico, Geográfico e Antropológico do Ceará imiscuíram-se em profundo debate em torno das teses "morenista" e "beckista". A cidade de Fortaleza nascera sob os auspícios do católico Martins Soares Moreno, na Barra do Ceará, como defenderam José Bonifácio de Souza e Ismael Pordeus n'O Nordeste, ou no entorno da Fortaleza de Schoonenborh, erguida a mando do calvinista Matias Beck, no entendimento de Luiz de Barros e Raimundo Girão? O debate começara quando uma comissão liderada pelo historiador Raimundo Girão sugeriu em anteprojeto que se batizasse uma importante avenida de Fortaleza com o nome do protestante holandês. Dispensado do cargo de Secretário de Urbanismo da Prefeitura de Fortaleza e entendendo o fundamento religioso da celeuma, Girão escreveu na primeira edição de Matias Beck - Fundador de Fortaleza (1961, p. 03) que "Se a crença de Matias Beck fosse a católica e portuguesa a sua nacionalidade, este livro não teria razão de ser". 
está na dúvida entre o que é realidade e sonho, é o instante de uma vacilação, o tempo da incerteza que está a meio caminho entre o real e o ilusório. Em duas dessas histórias Brasil afora, disseminou-se que os protestantes possuíam as partes do corpo de um bode e que eles o adoravam durante os cultos. A associação dos chifres e patas do caprino ao diabo ou à montaria das bruxas começou ainda com o cristianismo medieval e foi largamente usada para demonizar a imagem de papas e líderes protestantes, como Lutero, ao longo da era moderna ${ }^{15}$. Era de livre curso a crença do povo de que os protestantes escondiam nos sapatos "pés de bode". Em uma situação extrema, uma missionária de nome Charlotte teve que descalçar o sapato aos seus detratores (LÉONARD, 1981, p. 109). Se o fantástico está no instante de uma vacilação entre a explicação natural ou sobrenatural, a dúvida só pôde ser dissipada quando se constatou o pé humano descalço da missionária. Somente assim se impôs a crueza da realidade de um mundo desmagificado em que nenhuma pessoa poderia possuir pés como os de um bode. Balir em frente das igrejas ou, face a face, chamar um protestante de bode também ressonava esse imaginário ${ }^{16}$. Cortez (1965, p. 96) registrou em livro que, durante a sua estada no povoado de Acopiara, região norte do Estado do Ceará, o povo, indignado com a publicação de seus artigos em um jornal, dizia-lhe: "Eu hoje como carne de bode, 'inda' que seja bode magro".

O Correio do Ceará noticiou, em julho de 1943, um evento fantástico envolvendo o que chamou de "batistas mergulhões". O batismo em águas é uma doutrina incontornável para a denominação batista e simboliza a morte

15 O bode está associado ao sacrifício a Javé em indulgência dos pecados do povo hebreu, ao "bode expiatório atirado ao deserto", ou ainda ao mau-cheiro e à impureza. A imagem bode não é gratuita, remetendo-se, assim, ao juízo final e a seus condenados. As reminiscências da bestialização do diabo, ou seja, de sua transformação imagética discursiva de ente desencarnado para um ente encarnado na forma de animal, certamente haviam alcançado os sertões nordestinos. Os ecos dessa reminiscência encontram-se na reviravolta da demonologia do século XII, quando o diabo deixa de ser imaterial, etéreo, e passa a incorporar e dominar um corpo animal, inclusive o humano, instância última da luta entre este e o deus cristão.

16 Há duas versões sobre a origem da alcunha. O missionário americano Mein diz, no livro Os Batistas em Alagoas, página 9, que este apelido se originou da barbicha do rev. John Rocwell Smith, presbiteriano, que em 1874 tentou uma obra de evangelização em Maceió e que realmente usava "cavagnac". Aceitamos também a hipótese de uma possível caricatura corrente do Tio Sam, com sua barbicha e seus grandes pés, e em quem o espírito cáustico do povo certamente encontrou pontos de aproximação com a "coisa ruim" (LÉONARD, 1981, p. 109). No Dicionário Aurélio, constam outros sinônimos de protestante: comesanto, missa-seca, frei-bode, bíblia, crente etc. 
do 'velho Homem' e a confirmação da conversão. A carência de recursos para erguer um templo com um tanque batismal levou alguns pastores a realizar batismos em lagoas e rios. Em local indeterminado, o articulista informou que, às margens de um rio, reuniram-se adeptos e curiosos para a cerimônia. $\mathrm{O}$ pastor desceu o barranco, posicionou-se na água e deu o sinal para o fiel prender a respiração. De repente, uma sucuriú ou jacaré à espreita aproximouse e, ao terceiro mergulho, "a impiedosa fera chamou rapidamente o rapaz para o fundo do rio desaparecendo para sempre". Entre gritos e assombros, o pastor teria explicado à assistência que o neófito não fora levado por cobra ou jacaré, mas por obra do Espírito Santo. O texto finaliza com a seguinte admoestação: “É para evitar o 'Espírito' das serpentes, crocodilos e jacarés [...] que a igreja Católica não batiza seus filhos em beira de rios, açudes e lagoas". As histórias fantásticas sobre bodes, serpentes e jacarés, e que levava o povo a imaginar situações assustadoras, tinham um caráter pedagógico, pois buscavam impedir que o fiel tivesse a curiosidade em conhecer outra religião. A invenção dessas situações fantásticas envolvendo protestantes alimentou a religiosidade popular e fortaleceu a crença de que pessoas tinham marcas demoníacas e que podiam trazer infortúnio à comunidade.

\section{O pentecostalismo como baixo espiritismo}

Para além da rivalidade entre católicos e protestantes, outra se formou dos católicos e protestantes contra as igrejas pentecostais. Não é demais dizer que as igrejas protestantes encontraram seu 'Outro' no pentecostalismo. Portadoras do 'cristianismo autêntico', as igrejas protestantes deixaram contundentes páginas de estigmatização ao buscarem se diferenciar do pentecostalismo da primeira e segunda onda. Estigmatizar, porque as igrejas pentecostais e deuteropentecostais criam no batismo pelo Espírito Santo, realizavam exorcismos e curas. Diferenciar-se, em razão de que o catolicismo não distinguia protestantes de pentecostais.

Ao contrário do clero, os pastores batistas e presbiterianos não empregaram ações proibitivas diretas para barrar o avanço pentecostal na sua seara. Limitaram-se a censurá-los, advertindo as suas igrejas dos perigos da presença pentecostal no campo missionário. Por quê? Inicialmente, a acusação que lhes pesava era de que os missionários da Assembleia de Deus se infiltravam nas igrejas protestantes e as desviavam para o pentecostalismo. O que os missionários pentecostais chamavam de revival espiritual das 'frias' igrejas protestantes, os seus pastores entendiam como uma intolerável 
subversão. Os pentecostais "não procuram converter o mundo, os scepticos, mas os Protestantes, os crentes em geral", concluiu o pastor Pedro Tarsier n'O Jornal Batista de 25 de dezembro de 1930. Batizando presbiterianos e batistas no Espírito Santo, o entrismo pentecostal levou à disputa por clientes para o interior das próprias igrejas protestantes. Era uma estratégia eficaz de desfidelização pouco evidenciada pelos pesquisadores do pentecostalismo clássico $^{17}$. O entrismo foi o caso da Assembleia de Deus no Ceará. Quando do enriquecimento dos estados do Norte com o extrativismo da borracha, os imigrantes do Nordeste que tiveram contato com a doutrina do Espírito Santo, ao retornarem às suas cidades, estabeleceram as primeiras congregações e igrejas assembleianas ${ }^{18}$. Cearense de São Francisco, Serra de Uruburetama, e membro da Igreja Batista de Belém, Maria Nazaré foi a primeira convertida ao pentecostalismo no Brasil. Quando retornou ao Ceará, tentou, sem sucesso, converter seus pais e familiares. Todavia, em visita a uma Igreja Presbiteriana Independente, convenceu seus membros a aceitarem a doutrina do Espírito Santo, convertendo-a na primeira Igreja Assembleia de Deus no Ceará em 1914 (CONDE, [1960] 2000).

Uma segunda acusação ao pentecostalismo foi que eles praticavam uma espécie de baixo espiritismo. O termo estava associado à cultura banto da região Sudeste, e depois à herança africana de origem Iorubá e Nagô do Nordeste. Com o tempo, também passou a ser empregado para definir todas as religiões de transe ${ }^{19}$, às adivinhações, à manipulação de elixires, aos

17 A Assembleia de Deus foi, por quase toda a primeira metade dos Novecentos, a única igreja pentecostal no estado do Ceará. Partindo do Pará, os missionários da Assembleia de Deus seguiram para o Ceará (1914), Alagoas (1915), Pernambuco (1917), Rio Grande do Norte (1918), Paraíba (1918), Maranhão (1921), Piauí (1927), Sergipe (1927) e Bahia (1927) em um deslocamento inverso àquele realizado pelas igrejas protestantes no Oitocentos e início dos Novecentos.

18 Cinco elementos foram decisivos para o crescimento e a difusão do pentecostalismo pelo Nordeste e além: as periódicas estiagens que deslocaram nordestinos para o Norte, onde entraram em contato com o pentecostalismo; o beneficiamento com o trabalho protestante acumulado na região pelas igrejas presbiterianas e batistas, cujo caso extremo foi a conversão da IPI em AD no Ceará; a pregação simples feita por leigos, cujo conhecimento sobre o sagrado não vinha da formação regular em seminários, mas do 'alto', mediado pelo Espírito Santo, o que contribuiu para tornar cada convertido um pregador em potencial; o não aburguesamento precoce do ethos assembleiano; e a pregação às camadas populares com o oferecimento de serviços mágico-religiosos em cadência com o sistema de crenças do povo.

19 Às vezes empregados como sinônimos, transe e êxtase são diferentes estados. Para Marion Aubrée (1985), o êxtase é a saída de si, e o transe, a descida de uma divindade ou espírito. 
remédios secretos, às panaceias universais etc. Incomodado com a passagem pela cidade de Natal de duas missionárias assembleianas, Alexandrina Fernandes e Luiza Fernandes, o pastor Jerônimo Gueiros alertou, em artigo ao Norte Evangélico, de 1913, para os danos que já estavam causando no campo missionário paraense. Lamentou os prosélitos conquistados em dois anos de trabalho no Norte e Nordeste e denunciou-as dizendo que eram perigosas, porque vivem em "estado anormal em que se dizem baptizadas pelo Espírito Santo, estado de obsessão perigosa em que, como estou informado, caem convulsas, espumantes às vezes, gemendo, gritando, cantando, etc". O artigo adota o discurso médico-jurídico da época. Nele é insinuado que o culto pentecostal era um caso de polícia, pois colocava em perigo a ordem e a saúde pública. Tratava-se de um misto "revoltante de baixo espiritismo e occultismo de permeio com algumas doutrinas christãs desnaturadas", asseverou Gueiros. Naqueles dias, defendia-se, no meio protestante, que as autoridades públicas deviam dispensar aos pentecostais a mesma atenção e tratamento dado ao espiritismo, candomblé e à umbanda. Definir o pentecostalismo como um baixo espiritismo significava imputar-lhe um caráter sincrético com as religiões afro-brasileiras e o kardecismo ao mesmo tempo em que se buscava criminalizá-lo como um tipo novo de curandeirismo e charlatanismo, dois crimes passíveis de prisão por seis meses e multa de $100 \$$ a $500 \$ 000^{20}$.

Sempre que pôde, a imprensa protestante deu destaque às histórias que reforçavam essas ideias. Nos artigos publicados, buscava-se exagerar na releitura e ridicularizar as práticas de cura e expulsão de demônios. Era uma

Enquanto o êxtase é a plena memória do evento, o transe é a perda da consciência, a impossibilidade de acesso à memória. O êxtase advém da fixidez, do silêncio e da solidão, enquanto o transe beneficia-se do movimento e da polifonia de sons e palavras. Seguindo Gilbert Rouget (1985), Aubrée diferencia o transe de possessão do de inspiração. No transe de possessão, a exemplo da cerimônia xangô, o possuído muda de personalidade, transformando-se na divindade. Já no transe de inspiração, caracterizado pela glossolalia, o pentecostal conserva sua personalidade, mas ele está investido da divindade, que, dominando-o, faz dele o seu porta-voz. O êxtase seria o momento de 'intimidade com Deus'; e o transe, o batismo do Espírito Santo, a glossolalia, a agitação, o arrebatamento. Os conceitos de êxtase, transe e possessão não fazem parte do léxico pentecostal em nenhum tempo. No vocabulário próprio do pentecostalismo, diz-se derramar o Espírito, receber o Espírito Santo, cheio do Espírito, plenos do Espírito ou possuído pelo Espírito.

20 No discurso médico-jurista dos anos 1920-30, o charlatão é aquele que burla os códigos da disciplina médica, uma transgressão voluntária e consciente visando uma maior clientela, mais proventos pecuniários, etc. Já os curandeiros seriam um produto de indivíduos de pouca instrução, saídos das classes populares, que agem informados por concepções mágicas (Cf. GIUMBELLI, 2003). 
estratégia discursiva similar àquela empregada pelo clero em seus jornais para descredenciar o protestantismo, a exemplo do batista Pedro Tarsier que publicizou a história de uma mulher paulista casada com um recémconvertido que, estando doente, queria ser assistida por um médico. $\mathrm{O}$ esposo e outro homem teriam-lhe dito: "não, tu não vaes chamar médico, nós te curaremos pela fé". As orações dos "prophetas" não demonstraram nenhum efeito e a esposa insistiu que o marido chamasse o médico. Após amarrá-la, "começaram a expulsar o demônio com bofetadas". Em meio aos gritos, chegou a polícia: “[...] a infeliz, como tivesse um coração realmente cheio de amor, toda machucada, doente, e soluçando, ainda pediu aos presentes que perdoassem o peccado dos prophetas".

O clero também estava interessado em denunciar o pentecostalismo. Compartilhava, por motivos diferentes, as mesmas impressões com os pastores protestantes. A vigilante diocese de Sobral fez publicar, em 12 de abril de 1940, no Correio da Semana, os extratos de um livro escrito por um reverendo metodista. O livro trazia uma análise "dos seus processos de sugestões, passes, ataques, gritarias, convulsões e desmaios", além de citar "casos comprovados de curas fraudulentas". Deu destaque à histeria e à desordem do culto em que os crentes gemiam e choravam, "todos nervosos e muito fora de si". E, em tom anedótico, comentou com as suas palavras sobre um caso ocorrido no município Baixo Grande, Espírito Santo, de uma família que havia se convertido a uma igreja pentecostal. Segundo o clérigo, depois de "alguns dias de jejum e reuniões de gritaria", um dos membros da família recebeu uma "revelação": ele devia arrancar a língua de uma criancinha, pois ali estava "a antiga serpente". Enquanto puxava a língua da criança, "todas as outras pessoas da casa, em côro, repetiam: Aleluia, aleluia gloria a Jesus". Em dado momento, a mãe da criança recebeu outra revelação de que ela é quem precisava ser morta. O marido voltou-se para a mãe para cumprir a revelação: "A senhora esbofeteada pentecostalmente ficou de cama por alguns dias por causa das contusões recebidas no rosto". Ao final, destacou o pedido do pastor metodista por uma "ação enérgica do Sr. Delegado de polícia!" contra o "perigosíssimo" misto de "macumba protestante" e "baixo espiritismo". Comparado com outras denominações evangélicas, a "seita dos tremedores", disse, estava formada pelos mais "ignorantes, os mais fanáticos e os mais perniciosos de todos os protestantes". O clérigo ainda gracejou, perguntando o porquê do dom de línguas não ter se manifestado nos missionários aportados no Brasil vindo dos Estados Unidos. Se recebiam 
esse dom, por que eles passam tantos "meses a estudar o português para depois então pregar a tal doutrina de línguas?". Em outro artigo do órgão da diocese de Sobral, datado de maio de 1941, deu-se notícia de que só a "grande caridade cristã" das famílias do Crato para suportar os gemidos, zoadeiras e urros dos cultos da Assembleia de Deus durante a noite. "Fazia pena ver-se aquele salão cheio de pentecostais postos de-gatinhos, apoiados sobre mãos e pés, numa promiscuidade grotesca, como si quizessem assemelhar-se aos nossos animais domésticos". Atento ao resultado do culto, o articulista informou ainda que só três pessoas se converteram, "duas mulheres de vida livre e um barbeiro que conhecido como larápio perigoso andava sem freguezia", e foram batizadas em uma "poça de água de chuva enlameada".

A crítica ao pentecostalismo continuou com a chegada da Prece Poderosa, depois Igreja do Evangelho Quadrangular (IEQ) ${ }^{21}$, nos anos 1950. As premissas da crítica à segunda onda do pentecostalismo brasileiro permaneciam inalteradas: eram igrejas cuja religião assemelhava-se ao baixo espiritismo e praticava curandeirismos. Chamava a atenção que, nas tendas onde se realizavam os cultos de cura divina, se ofertava a dinheiro elixires à base de óleo de fígado de bacalhau e sal de fruta para o tratamento das mais diversas doenças ${ }^{22}$. Intitulado "Macumbas evangelísticas", o artigo de Emilio Warwick Kerr à revista Missionário Batista de 1954 retomou o mote do discurso médico-legal. Nele alertou que a prescrição de meios terapêticos durante os cultos era uma "hábil fuga às investigações legais do Serviço Sanitário". Impressionado, informou a facilidade com que os "missionários curandeiros" convenciam a audiência formada, em sua maioria, por membros da "classe operária" a dar "até o último centavo" de suas economias.

Que levantem ofertas vá lá, como coletas são levantadas em quase todos os vários cultos, mas, contribuições extras, no valor de milhares de cruzeiros, como

21 Só após a morte de Aimee Semple McPherson, a International Church of the Four-Square Gospel chegou ao Brasil. Foi estabelecida por Harold Williams e Raymond Boatright, em 1951, na cidade de São João da Boa Vista, São Paulo. Boatright pregava em tendas, vestia roupa xadrez e tocava guitarra elétrica durante os cultos. Debaixo de 24 tendas batizadas de tenda da cura divina ou tenda de Jesus, deu início à Cruzada no bairro de Cambuci, capital. Tornando-se um sucesso de público e mídia, criaram a Cruzada Nacional de Evangelização pelo interior de São Paulo e outros estados, como o Ceará em fins dos anos 1950 (Cf. FRESTON, 1993).

22 Na cidade de Fortaleza não existiram as famosas tendas que caracterizaram o formato dos cultos da IEQ. Foi em cultos sem proteção, ao ar livre, com um palanque e som, que a então Prece Poderosa chegou à capital nos anos 1960. 
temos visto em todas as tendas e em todas as reuniões das macumbas, é coisa de a polícia intervir e proibir terminantemente. Quando a classe trabalhadora enfrenta a falta de mantimentos estabelecida por um comércio inescrupuloso, mas sem intuitos sectários; quando aquilo que é impossível de esconder ou fraudar é vendido por preços acima das posses adquirentes do povo operário, com que direito, já sob pretextos religiosos, esses missionários viram ao avesso o bolso do pobre? Algo deve ser feito em benefício físico dos padecentes tiranizados pelo acicate de suas mazelas e ao governo é lícito verificar e cercear a concessão de passaportes à chusma de milagreiros que aqui aportaram sem outro milagre que aliviar a bolsa da gente pobre e subnutrida.

As insistentes comparações das igrejas pentecostais de primeira e segunda onda com as religiões mágicas e de transe podem estar na origem do comportamento anti-religiões afro-brasileiras, que marcariam o discurso neopentecostal a partir dos anos 1970. Ao estabelecer como alvo preferencial das pregações, além do catolicismo, o candomblé e a umbanda, as igrejas pentecostais criaram o seu ponto de fuga às críticas que as associavam ao baixo espiritismo. O pentecostalismo buscou se diferenciar das religiões afro-brasileiras - e do espiritismo - e desestigmatizar sua imagem social. Nas igrejas protestantes, as religiões afro-brasileiras eram percebidas como uma variante popular do catolicismo, e o alvo prioritário permanecia a Igreja Católica. As igrejas pentecostais adotaram, além do discurso anticatólico, o tropo da 'batalha espiritual' contra o candomblé, a umbanda e o espiritismo. Nesse sentido, antes de se tornar uma disputa pelo monopólio sobre a oferta das práticas mágicas e de transe (MARIANO, 1999; SILVA, 2007), demonizálas foi uma estratégia de diferenciação religiosa das igrejas neopentecostais. Ao mesmo tempo em que introduziam com sucesso a glossolalia, as curas, os exorcismos e as profecias no campo evangélico brasileiro, as igrejas centradas no Espírito Santo afirmavam sua identidade-como-diferença em relação às demais religiões mágicas e de transe.

\section{Considerações finais}

Até que ponto as ações proibitivas e de censura foram bem-sucedidas? Quando o poder público permitiu livre curso para agir, os resultados foram eficazes. O Estado vacilava peremptoriamente em cumprir a legislação e, até que se anunciasse o período de aggiornamento pós-Concílio Vaticano II, a Igreja continuava a entender como um abuso a noção de 'liberdade religiosa' e a tentativa de prosélitos em um país já cristianizado. Em algumas situações, a 
participação de agentes públicos junto com o clero foi decisiva nas ações, em outras foi o clero e seus seguidores que a garantiram. $\mathrm{Na}$ capital, Fortaleza, dominaram as ações proibitivas indiretas, na forma de censura por meio de jornais. O cosmopolitismo oligárquico, com seus dispositivos civilizatórios da urbanidade e racionalidade, somados à presença dos aparelhos de fiscalização e controle social inibiam as ações diretas, mantendo o conflito restrito à guerra de artigos nos jornais, livros e folhetos, e limitando-o à esfera da competência de quem fala a 'verdade' dos evangelhos e de quem está autorizado a interpretá-los. Já nos núcleos urbanos do sertão, a censura e as ações proibitivas diretas coexistiram e se complementaram. Os sertões, sejam os do Norte sejam os do Sul do país, são o espaço da dominação e exploração dos camponeses/sitiantes, de grilagem da terra, da apropriação particular dos benefícios públicos por oligarquias locais, e da frágil presença da justiça estatal e de serviços públicos. Rotinizada, a violência simbólica e física aparece como o modelo de conduta a ser seguido tanto pelos entes estatais como pelos entes privados, possibilitando os abusos e a aceitação de soluções baseadas na força.

O franco anticatolicismo das igrejas protestantes e, depois, das pentecostais, a posição social privilegiada do clero católico junto aos aparelhos de Estado, e o tipo de formação social ao qual um tipo popular de romanismo está vinculado aos estratos mais profundos da cultura local, com seus padres militantes e agentes carismáticos - santos, beatos e profetas, favoreceram uma situação de permanente tensão. Isto explica porque mais de dois terços das dezenas de casos anotados por Pedro Tarsier (1936) de enfrentamentos face a face ocorridos na primeira e segunda República terem ocorrido no interior, de Norte a Sul. Nesse sentido, as variações estratégicas e táticas para barrar o avanço protestante e pentecostal parecem não terem sido muito diferentes entre os estados.

Empiricamente, o pároco e o delegado são as personagens que encabeçam a lista dos mandos e desmandos no Ceará. As cidades de Juazeiro, Barbalha, Quixadá e Sobral, e circunvizinhanças, não devem ter sido as únicas nas quais ocorreram intimidações, expulsões, destruição de casas de culto e agressão física a protestantes. Foram, sim, os espaços em que se produziram as evidências materiais possíveis de serem pesquisadas e usadas na análise das ações face-a-face. Desta forma, nas cidades e nos povoados do interior, as ações proibitivas diretas apontam para um padrão que é global, isto é, de que dominava os enfrentamentos face a face e não raras vezes com a formação de 
Identificar, acusar, expulsar: rivalidades e 197 enfrentamentos religiosos no Brasil (1900-1960)

multidões. As ações proibitivas explicam o porquê do Ceará e outros estados do Nordeste possuírem um crescimento numérico vagaroso ao longo do primeiro Novecentos e mesmo depois. De modo geral, nos núcleos urbanos do interior, o crescimento evangélico continuaria vegetativo mesmo com o avanço do pentecostalismo. As ações proibitivas garantiram que os sertões permanecessem quase que herméticos à pregação protestante e pentecostal enquanto nas capitais se conseguia, a passos curtos, manter e ganhar adeptos.

\section{Referências}

ALVES, Rubem. Protestantismo e Repressão. São Paulo: Ática, 1982.

AUBRÉE, Marion. O Transe e a Resposta do Xangô e do Pentecostalismo. Ciência e Cultura. vol. 3, n. 7, p. 1070-1075, 1985.

A SEITA pentecostal. Correio da Semana, Sobral, p, 2, 4, 12. abr. 1940.

AVISO n 331. O Nordeste, Fortaleza, p. 02, 21 jan. 1950.

BATISMO protestante em beira de rio. Correia da Semana, Sobral, p. 01, 16 jul. 1943.

BATISTA, João. De Fortaleza. Correio Doutrinal, Bahia, p. 12, 08 ago. 1930.

BOUDIEU. Pierre. A distinção: crítica social do julgamento. São Paulo: Edusp; Porto Alegre, RS: Zouk, 2007.

BOUDON, Raymond. Tratado de Sociologia. Rio de Janeiro: Editora Zahar, 1995.

CAmargo, Cândido Procópio F. de (org). Católico, protestantes e espíritas. Petrópolis, RJ: Vozes, 1973.

CORTEZ, Natanael. Os dois tributos. A César a Deus. Fortaleza: [s.n.], 1965.

FERREIRA, Júlio A. História da Igreja Presbiteriana do Brasil. São Paulo: Casa Editora Presbiteriana, 1992. Volume 2.

FRESTON, Paul. Protestantes e política no Brasil: da Constituinte ao impeachment. 1993. 303 f. Tese (Doutorado em Sociologia) - Universidade de Campinas. São Paulo.

GIRÃO, Raimundo. Matias Beck - Fundador de Fortaleza. Fortaleza: Imprensa Oficial, 1961.

GIRARD, René. O bode expiatório. São Paulo: Paulus, 2004.

GIUMBELLI, Emerson. O "baixo espiritismo" e a história dos cultos mediúnicos. Horizontes Antropológicos. n. 19, p.247-281, 2003.

GUEIROS, Jerônimo. Um perigo no Estado. Norte Evangélico, Garanhuns, p. 01, 21 nov. 1913. HERVIEU-LÉGER, Danièle. La religion, hilo de memoria. Barcelona, Espanha: Herder, 2005. JESUS, Jaqueline Gomes de. Psicologia das massas: contexto e desafios brasileiros. Psicologia \& Sociedade. vol. 25, n. 3, p.493-503, 2013. 
KERR, Emilio Warwick. Macumbas evangelísticas. Missionário Batista, Out-Nov. 1954.

LÉONARD, Émile-Guillaume. O protestantismo brasileiro. Estudo de eclesiologia e história social. Rio de Janeiro: São Paulo: JUERP/ASTE, 1981.

LÖWY, Michael. Redenção e utopia. O judaísmo libertário na Europa Central. SP: Companhia das Letras, 1989.

MARIANO, Ricardo. Neopentecostais. São Paulo: Loyola, 1999.

MENDONÇA, Antônio Gouvêa; VELASQUES Filho, Prócoro. Introdução ao protestantismo no Brasil. São Paulo: Loyola, 1990.

OS PROTESTANTES proscrevem o nome de Jesus Cristo!!!. O Nordeste, Fortaleza, p. 01, 01 jun. 1922.

PARA longe o protestante. Correio da Semana, Sobral, p. 05, 31 mar. 1932.

PROPAGANDA protestante. Correio da Semana, Sobral, p. 3, 5, 02 maio 1941.

PROTESTANTES amparados. Correio da Semana, Sobral, p. 04, 05 mar. 1932.

ROSSI, Agnelo. Diretório Protestante no Brasil. Campinas: Tipografia Paulista, 1938.

RIBEIRO, Boanerges. Igreja evangélica e república brasileira (1889-1930). São Paulo: O Semeador, 1991.

RICOUER, Paul. Etapa atual do pensamento sobre a intolerância. In: A intolerância. Rio de Janeiro: Bertrand Brasil, 2000.

ROUGET, Gilbert. Music and trance. A theory of the relations between music and possession. Chicago: The University of Chicago Press, 1985.

TARSIER, Pedro. História das perseguições religiosas. São Paulo: Cultura Moderna, 1936. . O pentecostismo. O Jornal Batista. Rio de Janeiro, p. 6, 25 dez. 1930.

TODOROV, Tquetan. Introdução à Literatura Fantástica. São Paulo: Perspectiva, 2012.

SILVA. Vagner Gonçalves da. Neopentecostalismo e religiões afro-brasileiras: significados do ataque aos símbolos da herança religiosa africana no Brasil contemporâneo. Revista Mana, Rio de Janeiro, v. 1, n. 13. p.207-236, 2007.

SUMÁRIO de Culpa. Autora - Justiça Pública de Barbalha; Réu - A.S.B. Data - 03 de outubro de 1940. Arquivo Público do Estado do Ceará. Fortaleza.

VIANA, Paulo (org). A sagrada peleja. Fortaleza: Edições UFC/Casa José de Alencar, 2001. UMA viagem de colportagem. Norte Evangélico. Garanhuns, p. 02, 22 de ago. 1917.

Submetido em: 4-7-2019

Aceito em: 13-4-2020 